\title{
PEMBEKALAN ILMU KEWIRAUSAHA UNTUK GENERASI MUDA DALAM PERSAINGAN EKONOMI GLOBAL
}

\author{
Jeni Irnawati, Hadijah Febriana, Wirawan Suryanto, Sam Cay, Sri Sukapti \\ Program Studi Manajemen \\ Universitas Pamulang \\ dosen02228@unpam.ac.id
}

\begin{abstract}
Lembaga Pengabdian pada Masyarakat (LPM) is a media to bridge the world of education with the community where universities are faced with the problem of how citizens are able to face challenges. Further ahead in the era of globalization with entrepreneurship in the City of South Tangerang, one of the pilot projects that can be used as an opportunity to improve the welfare of the community through entrepreneurship opportunities. Entrepreneurship Counseling for the younger generation is to increase interest in knowledge and understanding of entrepreneurship as well as to grow young entrepreneurs. The outreach activities were carried out on October 21-23, 2019 at SMK Sasmita Jaya 1, Kota Tangerang Selatan. The number of participants was 30 young generation and Pamulang University students who have businesses with a variety of different businesses. The method used: lecture method, question and answer and discussion method. The provision of entrepreneurship knowledge contains material on the basics of entrepreneurship and entrepreneurial application so that it is expected to provide broader knowledge that can be directly applied in daily life and can change the mindset of young people in entrepreneurship. Further expectations in the future are of course needed by the South Tangerang Regional Government. And there needs to be closer and planned collaboration between the University and the Regional Government to explore the potentials in the region.
\end{abstract}

Keywords: Entrepreneurship; Young Generation

\begin{abstract}
Abstrak
Lembaga Pengabdian pada Masyarakat (LPM) merupakan suatu media untuk menjembatani dunia pendidikan dengan masyarakat dimana Perguruan Tinggi dihadapkan pada masalah bagaimana agar warga masyarakat mampu menghadapi tantangan. Lebih jauh ke depan di era globalisasi dengan berwirausaha di Kota Tangerang Selatan menjadi salah
\end{abstract}


satu pilot proyek yang dapat dijadikan peluang untuk meningkatkan kesejahteraan masyarakat melalui peluang berwirausaha. Penyuluhan Kewirausahaan bagi generasi muda ini adalah untuk meningkatkan minat dalam berwirapengetahuan dan pemahaman mengenai kewirausahaan sekaligus guna menumbuhkan pengusaha muda. Pelaksanaan kegiatan penyuluhan ini dilaksanakan pada tanggal 21-23 Oktober 2019 di SMK Sasmita Jaya 1, Kota Tangerang Selatan. Jumlah peserta sebanyak 30 orang generasi muda dan mahasiswa Universitas Pamulang yang memiliki usaha dengan berbagai usaha yang berbeda. Metode yang digunakan : metode ceramah, tanya jawab dan metode diskusi. Pembekalan ilmu kewirausahaan ini berisi materi tentang dasar-dasar kewirausahaan dan aplikasi kewirausahaan sehingga diharapkan memberikan pengetahuan yang lebih luas yang langsung dapat diterapkan dalam kehidupan sehari-hari dan dapat mengubah pola pikir generasi muda dalam berwirausaha. Harapan lebih jauh ke depan tentunya diperlukan tindak lanjut oleh Pemerintah Daerah Tangerang Selatan. Dan perlu dilakukan kerjasama yang lebih erat dan terencana antara Perguruan Tinggi dengan Pemerintah Daerah untuk menggali potensi-potensi yang ada di wilayah tersebut.

Kata kunci: Kewirausahaan; generasi muda

\section{A. PENDAHULUAN}

Kewirausahaan adalah sebuah proses mengidentifikasi, mengembangkan, dan membawa visi ke dalam kehidupan. Dalam bahasa Inggris, kewirausahaan disebut sebagai entrepreneurship. Orang yang menerapkan prinsip-prinsip kewirausahaan disebut sebagai wirausaha. Kewirausahaan memang membutuhkan sebuah visi, bisa berupa ide inovatif, peluang, atau cara dan langkah yang lebih baik dalam menjalankan sesuatu. Tentu dalam menjalankan prinsip-prinsip kewirausahaan terdapat ketidakpastian yang dikenal sebagai resiko atau hambatan. Menurut Suryana (2014:108), keberhasilan dalam kewirausahaan ditentukan oleh tiga faktor, yaitu yang mencakup hal-hal berikut:

1. Kemampuan dan kemauan. Orang yang tidak memiliki kemampuan, tetapi banyak kemauan dan orang yang memiliki kemauan, tetapi tidak memiliki kemampuan, keduanya tidak akan menjadi wirausahawan yang sukses. Sebaliknya, orang yang memiliki kemauan dilengkapi dengan kemampuan akan menjadi orang yang sukses. Kemauan saja tidak cukup bila tidak dilengkapi dengan kemampuan.

2. Tekad yang kuat dan kerja keras. Orang yang tidak meiliki tekad yang kuat, tetapi memiliki keamauan untuk bekerja keras dan orang yang suka bekerja keras, tetapi tidak memiliki tekad yang kuat, keduanya tidak akan menjadi wirausaha yang sukses.

3. Kesempatan dan peluang. Ada solusi ada peluang, sebaliknya tidak ada solusi tidak akan ada peluang. Peluang ada jika kita menciptakan peluang itu sendiri, bukan mencari-cari atau menunggu peluang yang datang kepada kita. 
Jadi, kemampuan berwirausaha merupakan fungsi dari perilaku kewirausahaan dalam mengombinasikan kreativitas, inovasi, kerja keras dan keberanian menghadapi resiko untuk memperoleh peluang. Seorang wirausahawan haruslah mampu melihat ke depan. Melihat ke deapan bukan melamun kosong, tetapi melihat, berfikir dengan penuh perhitungan, mencari pilihan dari berbagai alternatif masalah dan pemecahannya. Marbun dalam Alma (2011:52) mengemukakan untuk menjadi wirausahan, seseorang harus memiliki ciri-ciri:

\section{Percaya Diri}

Percaya diri dimulai dari pribadi yang mantap, tidak mudah terombang- ambing oleh pendapat dan saran orang lain. Akan tetapi, saran-saran orang lain jangan ditolak mentahmentah, pakai itu sebagai masukan untuk dipertimbangkan, kemudian anda harus memutuskan segera. Orang yang tinggi percaya dirinya adalah orang yang sudah matang jasmani dan rohaninya. Karakteristik kematangan seseorang adalah ia tidak tergantung pada orang lain, dia memiliki rasa tanggung jawab yang tinggi, obyektif dan kritis. Dia tidak begitu saja menyerap pendapat atau opini orang lain, tetapi dia mempertimbangkan secara kritis. Emosionalnya boleh dikatakan sudah stabil, tidak gampang tersinggung dan naik pitam, tingkat sosialnya tinggi dan mau menolong orang lain.

2. Berorientasi Pada Tugas dan Hasil

Orang ini tidak mengutamakan prestise dulu, prestasi kemudian. Akan tetapi, ia gandrung pada prestasi baru kemudian setelah berhasil prestisenya akan naik. Anak muda yang selalu memikirkan prestise lebih dulu dan prestasi kemudian tidak akan mengalami kemajuan. Berbagai motivasi akan muncul dalam bisnis jika kita berusaha menyingkirkan prestise. Kita akan mampu bekerja kras, enerjik, tanpa malu dilihat teman, asal yang kita kerjakan itu pekerjaan halal.

3. Pengambilan Resiko

Wirausaha juga penuh resiko dan tantangan, seperti persaingan, harga turun naik, barang tidak laku, dan sebagainya. Namun, semua tantangan ini harus dihadapi dengan penuh perhitungan. Jika perhitungan sudah matang, membuat pertimbangan dari segala macam segi, maka berjalanlah terus dengan tidak lupa berlindungkepada-Nya.

4. Kepemimpinan

Sifat kepemimpinan memang ada dalam diri masing-masing individu. Namun sekarang ini, sifat kepemimpinan sudah banyak dipelajari dan dilatih. Ini tergantung kepada masingmasing individu dalam menyesuaikan diri dengan organisasi atau orang yang ia pimpin. Pemimpin yang baik harus mau menerima kritik dari bawahan, ia harus bersifat responsif.

5. Keorisinilan

Sifat orisinil ini tentu tidak selau ada pada diri seseorang. Orisinil disini ialah ia tidak hanya mengekor pada orang lain, tetapi meiliki pendapat sendiri, ada ide yang orisinil, ada kemampuan untuk melaksankan sesuatu. Bobot kreativitas orisnil akan tampak sejauh manakah ia berbeda dari apa yang sudah ada sebelumnya.

6. Berorientasi ke Masa Depan

Seorang wirausaha harus perspektif, mempunyai visi ke depan, apa yang hendak ia lakukan, apa yang ingin ia capai, sebab sebuah usaha bukan didirikan untuk sementara tetapi untuk selamanya. Untuk menghadapi pandangan jauh kedepan, seorang wirausaha akan menyusun perencanaan dan strategi yang matang, agar jelas langkah-langkah yang akan dilaksanakan. 


\section{Kreativitas}

Kreativitas tinggi harus dimiliki setiap individu dalam bidang yang digeluti tak terkecuali dalam dunia wirausaha. Kewirausahaan merupakan gabungan kreativitas, inovasi dan keberanian hadapi resiko dengan bekerja keras membentuk dan memelihara usaha. Keberhasilan wirausaha akan tercapai apabila didukung dengan beragam faktor termasuk kreativitas. Kreativitas dapat dilatih dan bukan anugerah sejak lahir. Maka latih dan tingkatkan kreativitas anda untuk sukses.

Berdasarkan dari analisis situasi saat ini maka didapati permasalahan yang dihadapi saat ini adalah Tingkat Pengangguran Terbuka (TPT) untuk pendidikan Sekolah Menengah Kejuruan (SMK) menduduki posisi tertinggi sebesar 8,63\% (Februari 2019, Badan Pusat Statistik). Dengan kata lain, pada setiap 100 angkatan kerja lulusan Sekolah Menengah Kejuruan (SMK) masih ada 8 sampai dengan 9 orang lulusan Sekolah Menengah Kejuruan (SMK) saat ini menganggur. Lulusan Sekolah Menengah Kejuruan (SMK) yang belum sesuai dengan kebutuhan perusahaan sehingga menimbulkan banyaknya lulusan yang menganggur dan bekerja tidak sesuai dengan keterampilan yang mereka peroleh pada pendidikan sewaktu Sekolah Menengah Kejuruan (SMK). Selain itu Minat siswa untuk berwirausaha yang masih rendah dikarenakan kurangnya pengetahuan akan tahapan memulai usaha dan mempersiapkan mental pebisnis. Perekonomi kreatif tidak dapat terlepas dari generasi muda atau yang dikenal saat ini sebagai generasi millenial sebagai "gudang" kreativitas. Generasi muda atau generasi millenial adalah sumber daya yang produktif yang dengan ide kreatifnya dapat membuka sebuah usaha (wirausaha) yang juga membantu pemerintah dalam mengurangi tingkat pengangguran. Salah satu bentuk kreatifitas melalui kewirausahaan. Untuk mencapai target terciptanya wirausaha di dalam generasi muda maka kami sebagai dosen dari Universitas Pamulang akan melakukan Pengabdian Kepada Masyarakat dengan tema "Pembekalan Ilmu Kewirausahaan Untuk Generasi Muda Dalam Menghadapi Persaingan Ekonomi Global”.

\section{B. METODE PELAKSANAAN KEGIATAN}

Pelaksanaan kegiatan ini dilakukan selama 3 (tiga) hari dimulai dari tanggal 21-23 Oktober 2019 bertempat di SMK Sasmita Jaya 1, Tangerang Selatan. Pemberian pendidikan dan pelatihan secara langsung kepada masyarakat memerlukan biaya dan tenaga yang besar, waktu yang relatif lama, namun demikian dengan biaya dan tenaga yang terbatas khalayak sasaran yang strategis adalah siswa dan siswi SMK Sasmita Jaya 1, Kota Tangerang Selatan. Sehingga diharapkan melalui penyuluhan ini dapat menimbulkan minat usaha mandiri (berwirausaha) yang dapat meningkatkan pendapatan (income) keluarga, yang pada akhirnya akan meningkatkan taraf hidup dan kesejahteraan keluarga (masyarakat). Dengan melalui penyuluhan kewirausahaan ini diharapkan siswa dan siswi mempunyai bekal untuk berwirausaha dalam meningkatkan kesejahteraan masyarakat. Dan mampu menciptakan lapangan kerja baru secara mandiri sehingga dapat menampung dan memberikan lapangan kerja bagi pengangguran. Pelaksanaan kegiatan pembekalan ilmu kewirausahaan pada siswa dan siswi di SMK Sasmita Jaya 1, Kota Tangerang Selatan dimaksudkan untuk memberikan penyuluhan kewirausahaan kepada siswa dan siswi tentang pentingnya pengetahuan kewirausahaan sebelum mereka memulai suatu usaha apapun di masyarakat. Dengan potensi masyarakat yang ada diharapkan mereka mampu menyerap ilmu pengetahuan (transfer 
knowledge) dan bagaimana memanfaatkan dan mengimplentasikannya untuk mengatasi berbagai permasalahan hidup serta meningkatkan taraf hidup kearah yang lebih baik. Di samping itu mereka juga diberi pengetahuan tentang dasar-dasar kewirausahaan dan pengaplikasian kewirausahaan, sehingga semangat dan jiwa generasi muda dan pengusaha dalam kewirausahaan perlu terus ditumbuh kembangkan. Oleh karena itu kepada siswa dan siswi perlu diberikan pendidikan dan pelatihan melalui penyuluhan yang mengarah pada tumbuh dan meningkatnya kemandirian untuk menuju kehidupan yang lebih baik.

\section{HASIL DAN PEMBAHASAN}

Pelaksanaan pemaparan materi berupa seminar yang disampaikan oleh empat pemateri atau narasumber. Empat narasumber berasal dari tim dosen PKM UNPAM. Pemaparan materi pertama disampaikan oleh Kota Tangerang Selatan, Ibu Jeni Irnawati, S.E., M.M., menyampaikan kata sambutan sekaligus pembukaan acara PKM yang diadakan di SMK Sasmita Jaya 1, Tangerang Selatan. Selanjutnya pemaparan materi inti disampaikan oleh empat dosen dari tim PKM UNPAM, pertama Ibu Hadijah Febriana, S.E., M.M., menyampaikan materi terkait pembekalan ilmu tentang kewirausahaan, kedua Ibu Sam Cay, S.E., M.M., menyampaikan materi terkait contoh nyata wirausahawan muda yang sukses pada usia muda, ketiga Bapak Wirawan S.E., M.M., menyampaikan materi terkait jenis usaha apa yang cocok untuk siswa/siswi dan keempat materi disampaikan oleh Sri Sukapti, S.pd., M.M., yang memberikan motivasi kepada siswa/siswi agar semangat menjadi wirausahawan.

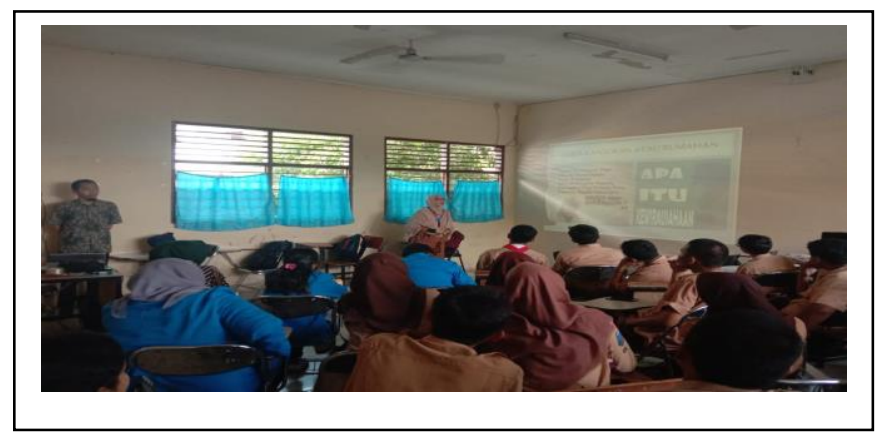

Gambar 1.

Pemberian Materi PKM

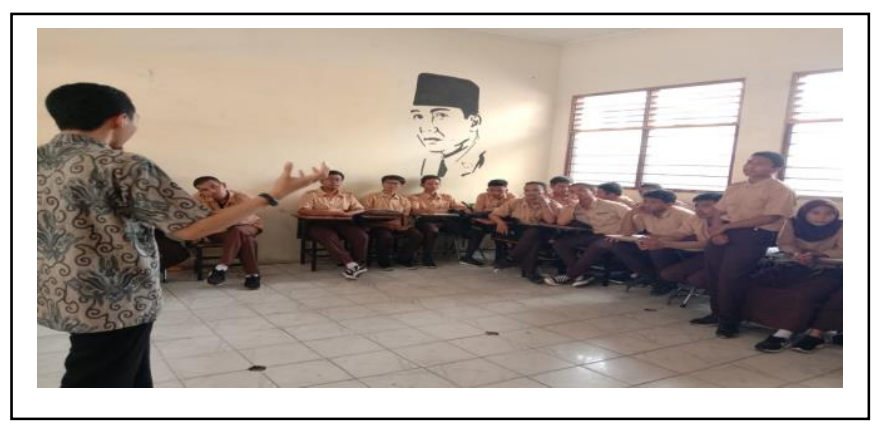

Gambar 2

Pemberian Materi PKM 
Keempatnya bersinergi memberikan pemaparan terkait dengan pembekalan ilmu kewirausahaan untuk siswa/siswi SMK. Pemberdayaan dapat melalui pengembangan zona baca, motivasi diri pengembangan karakteristik siswa/siswi, serta terkait penumbuhan semangat kewirausahaan. Juga disampaikan bagaimana memulai usaha dengan budget yang sangat kecil. Kegiatan diakhiri dengan diskusi dari peserta yang mempertanyakan permasalahan-permasalahan riil dalam dunia nyata berwirausaha karena kita menampilkan langsung contoh riil para wirausaha muda dan mudi di SMK Sasmita Jaya1, Pamulang. Pembahasan materi dan diskusi dilaksanakan di Kelas 12 SMK Sasmita Jaya 1 Lantai 2, pada pukul $13.30-15.45$ WIB.

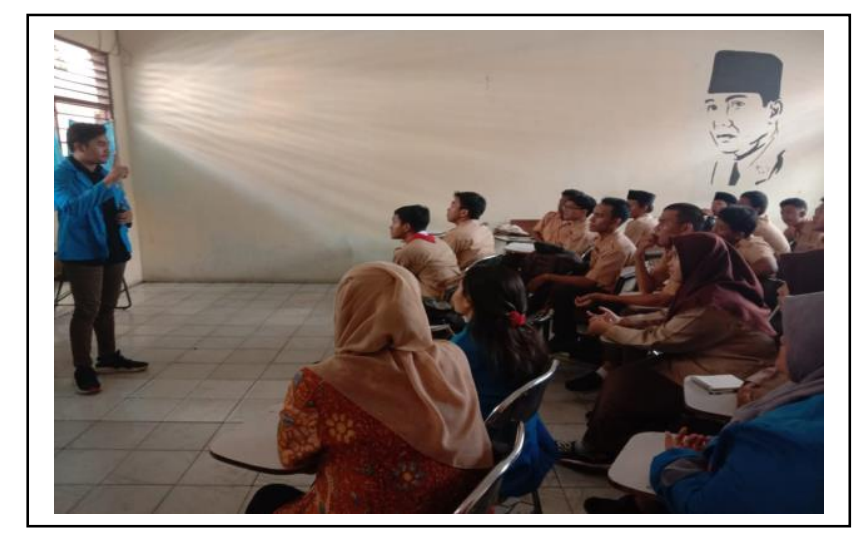

Gambar 3

Diskusi Tentang Berwirausaha

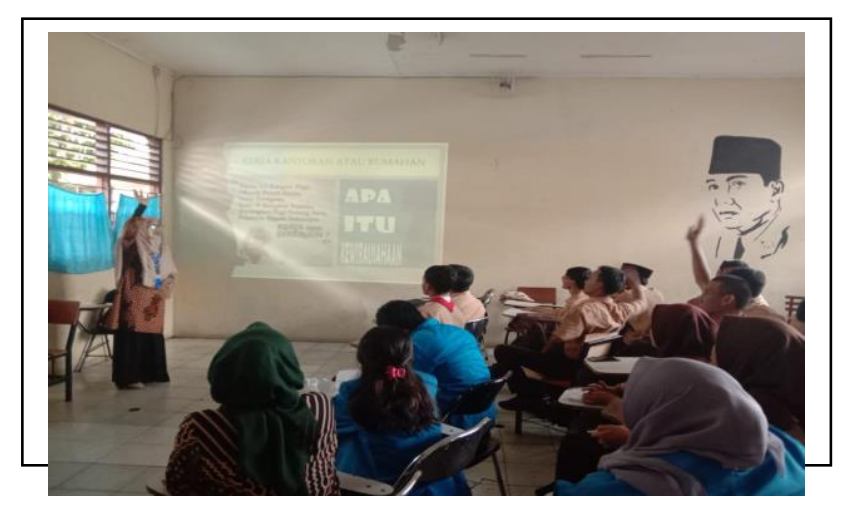

Gambar 4.

\section{Sesi Tanya Jawab}

Peserta terlihat sangat antusias dalam mengikuti seminar. Mereka mampu memaksimalkan kegiatan ini, karena seminar dilaksanakan dengan sistem diskusi sehingga peserta bisa bertanya dengan leluasa dan materi dapat tersampaikan secara maksimal. Tidak lupa pada seminar ini tim dosen melakukan ice breaking yang mampu mencairkan suasana, ditambah peran aktif moderator yang memandu kelancaran sesi materi dan tanya jawab, sehingga acara berjalan dengan kondusif. 


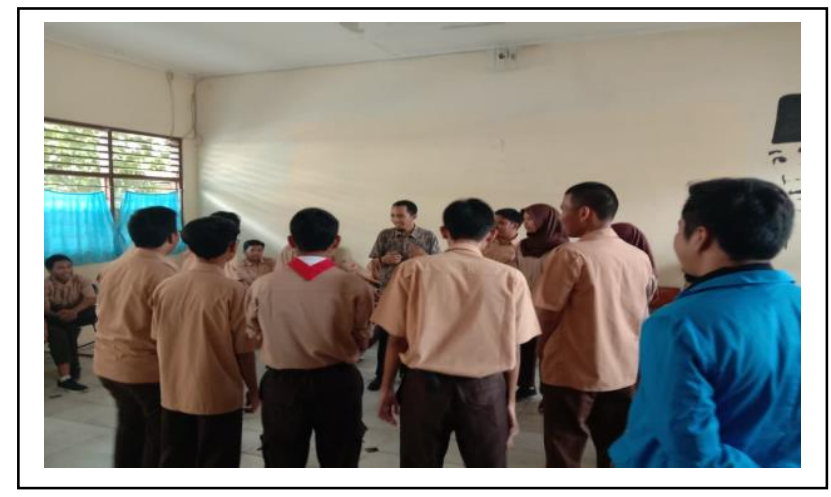

Gambar 5.

Ice breaking

\section{KESIMPULAN DAN SARAN}

\section{Simpulan}

1. Pengabdian kepada masyarakat mengenai pembekalan ilmu kewirausahaan kepada generasi muda khususnya siwa-siswi kelas XII di SMK Sasmita Jaya, Tangerang Selatan berisi materi tentang dasar-dasar kewirausahaan, faktor pendorong kewirausahaan serta memperkenalkan cara-cara membuka usaha baru.

2. Kegiatan pengabdian pada masyarakat dengan memberikan penyuluhan kewirausahaan menjadi jembatan bagi Perguruan Tinggi khususnya UNPAM dengan masyarakat dalam mentransfer wawasan ilmu kewirausahaan sehingga dapat langsung dirasakan manfaatnya oleh siswa-siswi SMK Sasmita Jaya 1, Tangerang Selatan.

\section{Saran}

Peserta dalam kegiatan pengabdian kepada masyarakat mengenai pembekalan ilmu kewirausahaan di SMK Sasmita Jaya 1, Tangerang Selatan sangat antusias dan memiliki keinginan yang kuat untuk mencoba berwirausaha pada saat mereka lulus nanti. Sebaiknya pemerintah daerah setempat dapat menindaklanjuti dengan menyediakan segala hal yang dibutuhkan berkaitan dengan prasarana dan sarana. Sehingga akan menumbuhkembangkan jiwa wirausaha bagi generasi muda.

\section{DAFTAR PUSTAKA}

Alma, B. (2011). Kewirausahaan untuk mahasiswa dan umum. Bandung: Alfa Beta.

Suryana. (2014). Kewirausahaan, Edisi IV. Jakarta: Salemba Empat. 